\title{
PENGARUH LIKUIDITAS, LEVERAGE, UKURAN PERUSAHAAN DAN PERTUMBUHAN PENJUALAN TERHADAP PROFITABILITAS
}

(Studi Pada Perusahaan Property dan Real Estate Yang Terdaftar di Bursa Efek Indonesia Tahun 2013-2017)

\section{OLEH}

\author{
DEDY SAMSUL ARIFIN \\ BUYUNG SARITA \\ RISKI AMALIA MADI \\ (Jurusan Manajemen Fakultas Ekonomi dan Bisnis Universitas Halu Oleo \\ Kendari)
}

\begin{abstract}
ABSTRAK
Penelitian ini bertujuan untuk menguji secara empiris faktor-faktor yang mempengaruhi Profitabilitas Perusahaan. Penelitian ini diuji dengan empat variabel independen yaitu Likuiditas, Leverage, Ukuran Perusahaan dan Pertumbuhan Penjualan. Objek pada penelitian ini adalah Perusahaan Property dan Real Esate yang terdaftar di Bursa Efek Indonesia dengan menggunakan teknik purposive sampling penulis memilih 29 Perusahaan Property dan Real Esate sebagai sampel. Penelitian ini menggunakan analisis data panel diperoleh dari laporan keuangan periode penelitian selama 5 tahun. Penelitian ini menggunakan data sekunder dengan bantuan aplikasi Eviews 9. Hasil penelitian menemukan bahwa current ratio (CR) memiliki pengaruh negatif dan signifikan terhadap return on asset (ROA), untuk debt to equity ratio (DER) memiliki pengaruh negatif dan tidak signifikan terhadap return on asset (ROA), sedangkan ukuran perusahaan memiliki pengaruh positif dan signifikan terhadap return on asset (ROA) dan pertumbuhan penjualan memiliki pengaruh positif dan signifikan terhadap return on asset (ROA).
\end{abstract}

Kata kunci : Profitabilitas, Likuiditas, Leverage, Ukuran Perusahaan dan Pertumbuhan Penjualan.

\begin{abstract}
I PENDAHULUAN
1.1 Latar Belakang

Perekonomian dunia yang membaik pasca terjadinya krisis global pada tahun 2008 memberikan dampak yang baik bagi investasi Indonesia, mengakibatkan terciptanya persaingan yang ketat dalam dunia bisnis yang tidak bisa dihindari. Persaingan bisnis yang kompetitif ini mengharuskan pelaku bisnis untuk meningkatkan kinerjanya agar dapat
\end{abstract}

mempertahankan kelangsungan hidup dan mencapai tujuan perusahaannya (Putra, 2015). 
Tabel 1.1

Tabel Perkembangan ROA Pada Perusahaan Property dan Real Estate Di Bursa Efek Indonesia Tahun 2013-2017

\begin{tabular}{|c|c|c|c|}
\hline TAHUN & TOTAL ASSET & LABA & ROA \\
\hline 2013 & $\operatorname{Rp} 4.796 .012 .055 .762$ & $\operatorname{Rp~} 441.737 .594 .222$ & $9 \%$ \\
\hline 2014 & $\operatorname{Rp} 5.682 .682 .514 .065$ & $\operatorname{Rp~} 500.738 .649 .441$ & $9 \%$ \\
\hline 2015 & $\operatorname{Rp} 6.552 .942 .143 .882$ & $\operatorname{Rp~} 405.377 .815 .486$ & $6 \%$ \\
\hline 2016 & $\operatorname{Rp} 4.479 .833 .059 .340$ & $\operatorname{Rp~} 240.464 .740 .544$ & $5 \%$ \\
\hline 2017 & $\operatorname{Rp} 5.017 .374 .760 .888$ & $\operatorname{Rp~334.999.763.456}$ & $7 \%$ \\
\hline Rata-rata & $\operatorname{Rp} 5.305 .768 .906 .787$ & $\operatorname{Rp~384.663.712.630}$ & $7 \%$ \\
\hline
\end{tabular}

Sumber : data sekunder yang diolah, 2018

Berdasarkan tabel 1.1 diatas, dapat dilihat bahwa perkembangan total asset, laba dan return on asset (ROA) pada perusahaan Property dan Real Estate dari tahun 2013-2017 mengalami fluktuasi. Dimana tingkat rata-rata total asset perusahaan dari tahun 2013-2017 sebesar Rp. 5.305.768.906.787, tingkat rata-rata laba perusahaan dari tahun 2013-2017 sebesar Rp. 384.663.712.630, dan tingkat rata-rata return on asset (ROA) perusahaan dari tahun 2013-2017 sebesar $7 \%$. Pada tahun 2014 ke tahun 2015 terjadi peningkatan total asset dari Rp 5.682.682.514.065 ke Rp. 6.552.942.143.882, sedangkan laba menurun dari Rp $500.738 .649 .441 \mathrm{ke}$ Rp. 405.377.815.486 serta ROA yang mengalami penurunan dari $9 \%$ menjadi $6 \%$. Jadi, dengan menurunnya presentase rata-rata profitabilitas dan fenomena ROA yang berfluktuasi dalam beberapa tahun tersebut mengindikasikan adanya faktor-faktor yang mempengaruhi profitabilitas pada perusahaan Property dan Real Estate di Bursa Efek Indonesia tahun 20132017.

$\begin{array}{rr}\text { Menurut Elfianto } & \text { Nugroho } \\ \text { (2011), perusahaan }\end{array}$ memaksimalkan labanya apabila manajer keuangan mengetahui faktorfaktor yang memiliki pengaruh besar terhadap profitabilitas perusahaan. Dengan mengetahui pengaruh dari masing-masing faktor terhadap profitabilitas, perusahaan dapat menentukan langkah-langkah yang efektif dan efisien untuk mengatasi masalah dan meminimalisir dampak negatif yang timbul (Ardiansyah et.al, 2017). Untuk memaksimalkan masingmasing faktor, diperlukan adanya manajemen asset, manajemen biaya, dan manajemen hutang (DiPietre et.al, 2007).

Likuiditas berhubungan dengan masalah kemampuan perusahaan untuk memenuhi kewajiban finansialnya yang harus segera dipenuhi (Riyanto, 2011). likuiditas menggambarkan kemampuan perusahaan untuk menyelesaikan kewajiban jangka pendeknya (Harahap, 2013:301). Menurut Husnan (2015:167), semakin likuid suatu aktiva maka semakin rendah kemampuan menghasilkan laba (profitabilitas) aktiva tersebut. Likuiditas dalam penelitian ini diproksikan dengan current ratio (CR) karena dapat menunjukkan bagaimana kemampuan perusahaan untuk membayar liabilitas jangka pendek dengan menggunakan aset lancarnya.

Penelitian yang dilakukan oleh Novi Sagita et., al (2015), menunjukkan bahwa likuiditas memiliki pengaruh negatif dan signifikan terhadap profitabilitas. Sedangkan penelitian yang dilakukan oleh Sylvia et.,al (2015), menunjukkan bahwa likuiditas memiliki pengaruh positif dan signifikan terhadap profitabilitas

Perusahaan juga membutuhkan pembiayaan atau tambahan modal dengan hutang atau leverage. Leverage adalah penggunaan aset dan sumber dana (sources of funds) oleh perusahaan yang memiliki biaya tetap dengan maksud agar meningkatkan keuntungan potensial pemegang 
saham (Sartono, 2010:123). Penggunaan hutang dalam kegiatan pendanaan perusahaan tidak hanya memberikan dampak yang baik bagi perusahaan. Jika proporsi leverage tidak diperhatikan perusahaan hal tersebut akan menyebabkan turunnya profitabilitas karena penggunaan hutang menimbulkan beban bunga yang bersifat tetap. Leverage dalam penelitian ini di proksikan dengan rasio debt to equity ratio.

Penelitian yang dilakukan oleh Nawaf et.,al (2015), Wela Yulia Putra et.,al (2015), Rudin M et., al (2016) dan Usman Ali et.,al (2018), menunjukkan bahwa leverage memiliki pengaruh negatif dan signifikan terhadap profitabilitas. Sedangkan penelitian yang dilakukan oleh Sylvia et.,al (2015), Dian et.,al (2016), Dwi Kartika et.al (2016) menunjukkan bahwa leverage memiliki pengaruh positif dan signifikan secara statistik terhadap profitabilitas

Setiap perusahaan pasti memiliki keinginan untuk selalu melaporkan pertumbuhan laba yang positif sehingga diharapkan dari hal tersebut mampu menarik minat investor untuk menanamkan modalnya. Ukuran perusahaan menggambarkan besar kecilnya yang dimiliki oleh suatu perusahaan (Sartono, 2010:249). Munawir (2007) menyebutkan bahwa perusahaan-perusahaan yang memiliki ukuran lebih besar memiliki dorongan yang kuat untuk menyajikan tingkat profitabilitas yang tinggi dibandingkan dengan perusahaan-perusahaan yang lebih kecil karena perusahaan yang lebih besar diteliti dan dipandang dengan lebih kritis oleh para investor. Namun tidak selalu ukuran perusahaan yang kecil tidak memiliki kinerja atau kekuatan yang baik, karena ukuran perusahaan bukan merupakan jaminan utama untuk menilai kinerja sebuah perusahaan.
Penelitian yang dilakukan oleh Andreani et.,al (2013), Asif lqbal et.,al (2015), Novi Sagita et.,al (2015), Dian et.,al (2016) dan Usman Ali et., al (2018) menunjukkan bahwa ukuran perusahaan memiliki pengaruh positif dan signifikan terhadap profitabilitas. Sedangkan penelitian yang dilakukan oleh Dwi Kartikasari et.,al (2016) menunjukkan bahwa ukuran perusahaan memiliki pengaruh negatif dan signifikan terhadap profitabilitas perusahaan

Penjualan merupakan kriteria penting untuk menilai profitabilitas perusahaan dan merupakan indikator utama atas aktivitas perusahaan (Andrayani, 2013). Pertumbuhan penjualan adalah kenaikan jumlah penjualan dari tahun ke tahun atau dari waktu ke waktu (Kennedy dkk., 2013). Pertumbuhan penjualan memiliki pengaruh yang strategis bagi perusahaan karena pertumbuhan penjualan ditandai dengan peningkatan market share yang akan berdampak pada peningkatan penjualan dari perusahaan sehingga akan meningkatkan profitabilitas dari perusahaan (Pagano dan Schivardi, 2003).

Penelitian yang dilakukan oleh Wela Yulia Putra et.,al (2015) menunjukkan bahwa pertumbuhan penjualan memiliki pengaruh negatif dan signifikan terhadap profitabilitas. Sedangkan penelitian yang dilakukan oleh Asif lqbal et.al (2015), Nawaf et., al (2015) dan Usman Ali et.,al (2018) menunjukkan bahwa pertumbuhan penjualan memiliki pengaruh positif dan signifikan terhadap profitabilitas.

Penelitian ini mengembangkan penelitian yang dilakukan oleh Rudin M.*, Djayani Nurdin and Vita Yanti Fattah (2016) dengan judul "The Effect Of Liquidity And Leverage On Profitability Of Property And Real Estate Company In Indonesian Stock Exchange within the period of 2005 until 
2010". Pengembangan penelitian dilakukan dengan menambah variabel bebas sesuai dengan keterbatasan penelti sebelumnya.

Berdasarkan uraian yang telah dipaparkan dalam latar belakang maka saya tertarik untuk mengangkat judul "Pengaruh Likuiditas, Leverage, Ukuran Perusahaan Dan Pertumbuhan Penjualan Terhadap Profitabilitas pada Perusahaan Property dan Real Estate Yang Terdaftar di Bursa Efek Indonesia Periode 2013 Sampai 2017."

\subsection{Rumusan Masalah}

Berdasarkan latar belakang di atas, maka permasalahan yang muncul dalam penelitian ini adalah sebagai berikut :

1. Apakah likuiditas, leverage, ukuran perusahaan dan pertumbuhan penjualan secara simultan berpengaruh terhadap profitabilitas pada perusahaan Property dan Real Estate di Bursa Efek Indonesia?

2. Apakah likuiditas berpengaruh terhadap profitabilitas pada perusahaan Property dan Real Estate di Bursa Efek Indonesia?

3. Apakah leverage berpengaruh terhadap profitabilitas pada perusahaan Property dan Real Estate di Bursa Efek Indonesia?

4. Apakah ukuran perusahaan berpengaruh terhadap profitabilitas pada perusahaan Property dan Real Estate di Bursa Efek Indonesia?

5. Apakah pertumbuhan penjualan berpengaruh terhadap profitabilitas pada perusahaan Property dan Real Estate di Bursa Efek Indonesia.?

\subsection{Tujuan Penelitian}

Sesuai dengan permasalahan yang diajukan, maka tujuan dari penelitian ini adalah sebagai berikut:
1. Untuk mengetahui pengaruh likuiditas, leverage, ukuran perusahaan dan pertumbuhan penjualan secara simultan terhadap profitabilitas pada perusahaan Property dan Real Estate di Bursa Efek Indonesia.

2. Untuk mengetahui pengaruh likuiditas terhadap profitabilitas pada perusahaan Property dan Real Estate di Bursa Efek Indonesia.

3. Untuk mengetahui pengaruh leverage terhadap profitabilitas pada perusahaan Property dan Real Estate di Bursa Efek Indonesia.

4. Untuk mengetahui pengaruh ukuran perusahaan terhadap profitabilitas pada perusahaan Property dan Real Estate di Bursa Efek Indonesia.

5. Untuk mengetahui pengaruh pertumbuhan penjualan terhadap profitabilitas pada perusahaan Property dan Real Estate di Bursa Efek Indonesia.

\subsection{Manfaat Penelitian}

Penelitian ini diharapkan dapat memberikan manfaat kepada beberapa pihak antara lain sebagai berikut :

\subsubsection{Manfaat Teoritis}

Bagi akademisi, bisa dijadikan literatur atau informasi unutuk penelitian berikutnya dan melengkapi penelitian-penelitian sebelumnya serta memberikan informasi, referensi tambahan mengenai sejauh mana pengaruh likuiditas, leverage, ukuran perusahaan dan pertumbuhan penjualan terhadap profitabilitas.

\subsubsection{Manfaat Praktis \\ 1.4.2.1 Bagi investor dan calon investor}

Diharapkan memberikan informasi yang akan digunakan sebagai penilaian terhadap suatu prospek perusaaan dimasa yang akan datang dan dapat menjadi input 
informasi terkait dengan pengambilan keputusan di dalam kegiatan investasi.

\subsubsection{Bagi Perusahaan}

Hasil penelitian ini diharapkan dapat digunakan sebagai salah satu dasar pertimbangan didalam pengambilan keputusan dalam bidang keuangan terutama dalam rangka memaksimumkan laba perusahaan dengan memperhatikan faktor-faktor yang diteliti dalam penelitian ini.

\subsection{Ruang Lingkup Penelitian}

Pada penelitian ini, penulis memberi batasan pada ruang lingkup permasalahan. Adapun ruang lingkup permasalahan dalam penelitian ini adalah Profitabilitas sebagai variabel dependen dan terdapat empat variabel independen yaitu Likuiditas, leverage, ukuran perusahan dan pertumbuhan penjualan . Objek penelitian ini perusahaan Property dan Real Estate di Bursa Efek Indonesia periode 2013 2017.

\section{TINJAUAN PUSTAKA}

\subsection{Landasan Teori}

Landasan teori dimaksudkan sebagai rujukan teori yang relevan yang digunakan untuk menjelaskan tentang variabel yang akan diteliti sebagai dasar untuk memberi jawaban sementara terhadap rumusan masalah yang diajukan (hipotesis) dan penyusunan instrumen penelitian. Adanya landasan teoritis ini merupakan ciri bahwa penelitian itu merupakan cara ilmiah untuk mendapatkan data (Sugiyono, 2012). Variabel penelitian ini adalah likuiditas, leverage, ukuran perusahaan dan pertumbuhan penjualan serta profitabilitas.

\subsubsection{Profitabilitas}

Profitabilitas

menunjukan

kemampuan perusahaan untuk menghasilkan laba selama periode tertentu (Sunyoto, 2013:61). Profitabilitas suatu perusahaan diukur dengan kesuksesan perusahaan dan kemampuan menggunakan aktivanya secara produktif, dengan demikian profitabilitas suatu perusahaan dapat diketahui dengan memperbandingkan antara laba yang diperoleh dalam periode tertentu dengan jumlah aktiva atau jumlah modal perusahaan tersebut (Sunyoto, 2013).

\subsubsection{Likuiditas}

Likuiditas berhubungan dengan

masalah kemampuan suatu perusahaan untuk memenuhi kewajiban finansialnya yang akan segera harus dipenuhi (Riyanto, 2011). Rasio likuiditas mengukur kemampuan likuiditas jangka pendek perusahaan dengan melihat aktiva lancar perusahaan relatif terhadap utang lancarnya (utang dalam hal ini merupakan kewajiban perusahaan) (Halim, 2015).

\subsubsection{Leverage}

Leverage adalah penggunaan aset dan sumber dana (sources of funds) oleh perusahaan yang memiliki biaya tetap dengan maksud agar meningkatkan keuntungan potensial pemegang saham (Sartono, 2010:123). Leverage biasanya dipergunakan untuk menggambarkan kemampuan perusahaan untuk menggunakan aktiva atau dana yang mempunyai beban tetap (fixed cost assets or funds) untuk memperbesar tingkat penghasilan (return) bagi pemilik perusahaan (Syamsuddin, 2009:89). Penggunaan hutang dalam kegiatan pendanaan perusahaan tidak hanya memberikan dampak yang baik bagi perusahaan. Jika proporsi leverage tidak diperhatikan perusahaan, hal tersebut akan menyebabkan turunnya profitabilitas, karena penggunaan hutang menimbulkan beban bunga yang bersifat tetap.

\subsubsection{Ukuran Perusahaan}

Ukuran perusahaan merupakan suatu penetapan besar kecilnya perusahaan. Dalam penelitian ini, ukuran perusahaan yang dimaksud adalah aktiva (assets). Secara 
sederhana, aktiva (assets) dapat didefinisikan sebagai sumber daya yang dikuasai oleh perusahaan sebagai akibat di masa depan diharapkan akan diperoleh perusahaan (Jusuf ,2014: 7).

\subsubsection{Pertumbuhan Penjualan}

Pertumbuhan

penjualan

merupakan perubahan penjualan pada laporan keuangan per tahun (Fabozzi, 2000:881). Pertumbuhan penjualan di atas rata-rata bagi suatu perusahaan umumnya didasarkan pada pertumbuhan yang cepat yang diharapkan dari industri dimana perusahaan itu beroperasi. Perusahaan dapat mencapai tingkat pertumbuhan di atas rata-rata dengan jalan meningkatkan pangsa pasar dari permintaan industri keseluruhan.

\subsection{Balancing Theory}

Balancing theory merupakan keseimbangan antara manfaat dan pengorbanan yang timbul sebagai akibat penggunaan hutang (Husnan, 1998). Sejauh manfaat masih besar, hutang akan ditambah. Tetapi bila pengorbanan menggunakan hutang sudah lebih besar maka hutang tidak lagi ditambah. Hal ini disebabkan karena adanya biaya kebangkrutan, biaya modal sendiri akan naik dengan tingkat yang makin cepat. Sebagai akibatnya, meskipun memperoleh manfaat penghematan pajak dari penggunaan hutang yang besar berdampak oleh kenaikan biaya modal sendiri yang tajam, sehingga berakhir dengan menaikkan biaya perusahaan.

\subsection{The Pecking Order Theory}

Pecking Order Theory juga disebut sebagai teori asimetri informasi yang diusulkan oleh Ross (1996), Fama \& French (2004) menunjukkan bahwa perusahaan lebih memilih untuk membiayai investasi baru, pertama secara internal dengan laba ditahan, kemudian dengan utang dan akhirnya dengan masalah ekuitas baru.

\subsection{Penelitian Terdahulu}

Penelitian ini dibuat dan disusun berdasarkan pada beberapa penelitian terdahulu yang memiliki topik yang sama sebagai bahan referensi antara lain sebagai berikut :

\section{Andreani Caroline Barus, Leliani (2013) \\ Penelitian yang dilakukan oleh} Andreani Caroline Barus, Leliani (2013), berjudul "Analisis Faktor-faktor yang Mempengaruhi Profitabilitas Pada Perusahaan Manufaktur yang Terdaftar di BEl". Populasinya adalah perusahaan manufaktur yang terdaftar di Bursa Efek Indonesia periode 20082011 sebanyak 131 perusahaan. Teknik pengambilan sampel menggunakan purposive sampling dan diperoleh sebanyak 43 perusahaan. Metode pengujian menggunakan analisis regresi linier berganda. Hasil penelitian menunjukkan bahwa Total Asset Turnover, Debt Ratio dan ukuran perusahaan memiliki pengaruh positif signifikan terhadap profitabilitas perusahaan, sedangkan Current Ratio, Debt to Equity Ratio, dan pertumbuhan penjualan tidak memiliki pengaruh signifikan terhadap profitabilitas perusahaan.

Persamaan penelitian terdahulu dengan penelitian saat ini adalah variabel independen (likuiditas, leverage, ukuran perusahaan dan pertumbuhan penjualan) dan variabel dependennya (profitabilitas) serta teknik analisis data regresi linier berganda. Sedangkan perbedaannya terletak pada periode tahun penelitian dan objek penelitian.

\section{KERANGKA KONSEP DAN HIPOTESIS}




\section{METODE PENELITIAN \\ 4.1 Jenis Penelitian}

Jenis penelitian yang digunakan oleh peneliti adalah penelitian dengan metode Eksplanatif. Peneltian eksplanatif merupakan penelitian yang melakukan pengujian terhadap sebuah prediksi teori atau hipotesis hasil penelitian yang sudah ada dengan menjelaskan hubungan sebab-akibat (Neuman, 2007). Tujuan dari penelitian eksplanatif juga menjelaskan pola hubungan yang terjadi antara dua variabel atau lebih, selain itu penelitian ini mencoba melihat dan menjelaskan pengaruh dari likuiditas, leverage, ukuran perusahaan dan pertumbuhan penjualan terhadap profitabilitas.

\subsection{Objek Penelitian}

Objek penelitian merupakan suatu atribut atau sifat atau nilai dari orang, objek atau kegiatan yang mempunyai variabel tertentu yang ditetapkan untuk dipelajari dan ditarik kesimpulan (Sugiyono, 2012). Objek dalam penelitian ini adalah perusahaan property dan real estate yang terdaftar di bursa efek Indonesia 2013-2017.

\subsection{Populasi dan Sampel \\ 4.3.1 Populasi}

Populasi diartikan sebagai wilayah generalisasi yang terdiri atas

obyek/subyek yang mempunyai kualitas dan karateristik tetentu yang ditetapkan oleh peneliti untuk dipelajari dan kemudian ditarik kesimpulannya
(Sugiyono, 2012:119). Dalam penelitian ini, populasi yang diambil merupakan perusahaan yang bergerak di sektor property dan real estate dan terdaftar sebagai publik (emiten) yang terdaftar di Bursa Efek Indonesia (BEI) tahun 2013-2017. Jumlah perusahaan Property dan Real Estate yang go public sampai tahun 2017 berjumlah 50 perusahaan.

\subsubsection{Sampel}

Sampel adalah bagian dari jumlah dan karakteristik yang dimiliki oleh populasi tersebut (Sugiyono, 2012). Penelitian ini mengambil sampel perusahaan yang bergerak di sektor Property dan Real Estate yang terdaftar di BEI karena perusahaan property dan real estate di Indonesia sangat berkembang pesat, hal itu berarti perusahaan property dan real estate akan memiliki ruang lingkup yang sangat besar.

Pengambilan sampel dalam penelitian ini menggunakan purposive sampling. Sugiyono (2012:126) menjelaskan bahwa purposive sampling adalah teknik penentuan sampel dengan pertimbangan tertentu. Adapun tujuan dari metode ini adalah untuk mendapatkan sampel atas pertimbangan tertentu dengan kriteriakriteria yang telah ditentukan dengan tujuan mendapatkan sampel yang representative. Adapun kriteria yang digunakan untuk memilih sampel pada penelitian ini adalah sebagai berikut :

1. Perusahaan property dan real estate yang terdaftar di Bursa Efek Indonesia (BEI) tahun 2017.

2. Perusahaaan tersebut menerbitkan laporan tahunan (annual report) di Bursa Efek Indonesia (BEl) secara 
berturut-turut selama tahun pengamatan pada tahun 20132017.

3. Perusahaan property dan real estate yang selalu menghasilkan laba atau tidak mengalami kerugian selama periode penelitian pada tahun 2013-2017.

4. Perusahaan menggunakan mata uang rupiah dalam laporan keuangannya.

Tabel 4.1 Kriteria Sampel Penelitian

\begin{tabular}{|l|l|c|}
\hline No. & \multicolumn{1}{|c|}{ Kriteria } & Jumlah \\
\hline 1. & $\begin{array}{l}\text { Perusahaan property dan real estate yang terdaftar di Bursa Efek Indonesia (BEI) tahun } \\
2017\end{array}$ & 50 \\
\hline 2. & $\begin{array}{l}\text { Perusahaan property dan real estate yang menerbitkan laporan keuangan tahunan (Annual } \\
\text { Report) dari tahun 2013-2017 }\end{array}$ & 40 \\
\hline 3 & $\begin{array}{l}\text { Perusahaan property dan real estate yang selalu menghasilkan laba atau tidak mengalami } \\
\text { kerugian selama periode penelitian dari tahun 2013-2017. }\end{array}$ & 29 \\
\hline \multicolumn{1}{|c|}{ Jumlah Sampel } & 29 \\
\hline
\end{tabular}

Sumber : Data diolah, 2018

Pada Tabel 4.1 di atas menunjukkan bahwa jumlah populasi dalam penelitian ini sebanyak 50 perusahaan dengan periode penelitian selama lima tahun yaitu tahun 20132017 pada perusahaan Property dan Real Estate yang terdaftar di Bursa Efek Indonesia. Setelah dipilah dengan

\section{Tabel 4.2}

Daftar Perusahaan yang Menjadi Sampel Penelitian

\begin{tabular}{|c|c|c|}
\hline No & Koda Saham & Nama Perusahaan \\
\hline 1 & APLN & Agung Podomoro Land Tbk \\
\hline 2 & ASRI & Alam Sutera Realty Tbk \\
\hline 3 & BAPA & Bekasi Asri Pemuda Tbk \\
\hline 4 & BEST & Bekasi Fajar Industrial Estate Tbk \\
\hline 5 & BKSL & Sentul City Tbk \\
\hline 6 & BSDE & Bumi Serpong Damai Tbk \\
\hline 7 & CTRA & Ciputra Development Tbk \\
\hline 8 & DART & Duta Anggada Realty Tbk \\
\hline 9 & DILD & Intiland Development Tbk \\
\hline 10 & DUTI & Duta Pertiwi Tbk \\
\hline 11 & EMDE & Megapolitan Development Tbk \\
\hline 12 & GAMA & Gading Development Tbk \\
\hline 13 & GMTD & Gowa Makassar Tourism Development Tbk \\
\hline 14 & GPRA & Perdana Gapuraprima Tbk \\
\hline 15 & GWSA & Greenwood Sejahtera Tbk \\
\hline 16 & JRPT & Jaya Real Property Tbk \\
\hline 17 & KIJA & Kawasan Industri Jababeka Tbk \\
\hline 18 & LPCK & Lippo Cikarang Tbk \\
\hline 19 & LPKR & Lippo Karawaci Tbk \\
\hline 20 & MDLN & Modernland Realty Ltd Tbk \\
\hline 21 & MKPI & Metropolitan Kentjana Tbk \\
\hline 22 & MTLA & Metropolitan Land Tbk \\
\hline 23 & PLIN & Plaza Indonesia Realty Tbk \\
\hline 24 & PWON & Pakuwon Jati Tbk \\
\hline 25 & RDTX & Roda Vivatex Tbk \\
\hline 26 & RODA & Pikko Land Development Tbk \\
\hline 27 & SCBD & Danayasa Arthatama Tbk \\
\hline 28 & SMDM & Suryamas Dutamakmur Tbk \\
\hline 29 & SMRA & Summarecon Agung Tbk \\
\hline
\end{tabular}

Sumber : Factbook Bursa Efek Indonesia 2017
4.4 Jenis Data dan Sumber Data
4.4 .1
Jenis Data

dijelaskan di atas, maka sampel yang didapat sebanyak 29 perusahaan Property dan real estate yang layak dijadikan sampel dalam penelitian ini. Berikut daftar perusahaan yang menjadi sampel penelitian : 
Jenis data yang digunakan dalam penelitian ini adalah data kuantitatif. Menurut Silalahi (2010 : 282), data kuantitatif merupakan data hasil serangkaian observasi atau pengukuran yang dinyatakan dalam angka. Data kuantitatif berdasarkan klasifikasi waktu dapat di kategorikan sebagai data time series (runtut waktu), cross section dan data panel. Dalam penelitian ini data yang digunakan adalah data pannel, yaitu gabungan antara data time series dan data cross section.

\subsubsection{Sumber Data}

Sumber data ada dua yaitu data primer dan data sekunder. Data primer adalah data yang bersumber langsung dari orang pertama yang disebut "first hand information." Data sekunder adalah data yang dikumpulkan dari tangan kedua atau dari sumber-sumber lain yang telah tersedia sebelum penelitian dilakukan (Silalahi, 2010:291). Sumber data yang digunakan dalam penelitian ini adalah data sekunder di, Indonesia Stock Exchange (IDX) tahun 2013-2017.

\subsection{Metode Pengumpulan Data}

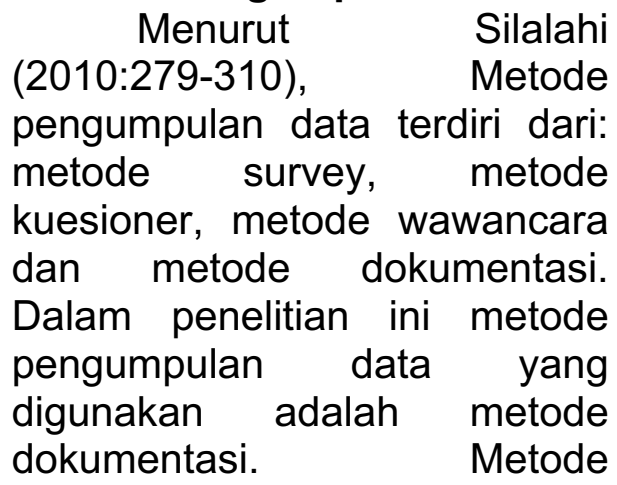

dokumentasi adalah cara yang

dilakukan oleh peneliti untuk

memperoleh data melalui dokumen, mengkaji buku-buku, jurnal dan makalah untuk dapat landasan teoritis yang komperhensif serta eksplorasi laporan keuangan dari laporan tahunan (Annual Report) perusahaan manufaktur. Data diperoleh dengan cara mengutip langsung dari laporan keuangan tahunan selama 5 tahun berturut-turut yaitu dari tahun 20132017.

\section{BAB V HASIL PENELITIAN DAN PEMBAHASAN}

5.1 Pemilihan Model (Teknik Estimasi) Regresi Data Panel 5.1.1 Uji Chow

Uji chow dilakukan untuk memilih apakah common effect model atau fixed effect model yang lebih tepat digunakan dalam model persamaan regresi data panel. Untuk membandingkan common effect model dengan fixed effect model maka dilakukan uji F statistik. Uji $F$ pada dasarnya digunakan untuk membandingkan antara model common effect yang mengansumsikan model intersep untuk semua unit cross section sama dengan model fixed effect yang mengansumsikan bahwa berbeda dengan cross section.

Tabel 5.7 Hasil Uji Chow

\begin{tabular}{|lllr|}
\hline Redundant Fixed Effects Tests & & \\
Pool: KODE_PERUSAHAAN \\
Test cross-section fixed effects
\end{tabular}




\begin{tabular}{|c|c|c|c|c|}
\hline \multicolumn{5}{|l|}{ Cross-section Chi-square } \\
\hline \multicolumn{5}{|c|}{$\begin{array}{l}\text { Cross-section fixed effects test equation: } \\
\text { Dependent Variable: ROA? } \\
\text { Method: Panel Least Squares } \\
\text { Date: } 02 / 27 / 19 \text { Time: } 20: 23 \\
\text { Sample: } 15 \\
\text { Included observations: } 5 \\
\text { Cross-sections included: } 29 \\
\text { Total pool (balanced) observations: } 145\end{array}$} \\
\hline Variable & Coefficient & Std. Error & t-Statistic & Prob. \\
\hline $\begin{array}{c}\text { C } \\
\text { CR? } \\
\text { DER? } \\
\text { SIZE? } \\
\text { GROWTH? }\end{array}$ & $\begin{array}{r}4.665302 \\
-0.501119 \\
-1.014561 \\
0.311787 \\
4.594872\end{array}$ & $\begin{array}{l}3.152697 \\
0.261815 \\
0.856284 \\
0.261625 \\
0.923980\end{array}$ & $\begin{array}{r}1.479781 \\
-1.914021 \\
-1.184841 \\
1.191735 \\
4.972912\end{array}$ & $\begin{array}{l}0.1412 \\
0.0577 \\
0.2381 \\
0.2354 \\
0.0000\end{array}$ \\
\hline $\begin{array}{l}\text { R-squared } \\
\text { Adjusted R-squared } \\
\text { S.E. of regression } \\
\text { Sum squared resid } \\
\text { Log likelihood } \\
\text { F-statistic } \\
\text { Prob(F-statistic) }\end{array}$ & $\begin{array}{r}0.186008 \\
0.162751 \\
4.904273 \\
3367.265 \\
-433.7675 \\
7.997966 \\
0.000008\end{array}$ & \multicolumn{2}{|c|}{$\begin{array}{l}\text { Mean dependent var } \\
\text { S.D. dependent var } \\
\text { Akaike info criterion } \\
\text { Schwarz criterion } \\
\text { Hannan-Quinn criter. } \\
\text { Durbin-Watson stat }\end{array}$} & $\begin{array}{l}7.041796 \\
5.359785 \\
6.051965 \\
6.154611 \\
6.093674 \\
0.830836\end{array}$ \\
\hline
\end{tabular}

\section{Sumber: Hasil Olahan Eviews 9}

Berdasarkan tabel 5.7, dapat dilihat bahwa nilai probabilitas (Prob) untuk cross-section Chi-square sebesar 0,0000 yang niainya $<0,05$. Sehingga dapat disimpulkan bahwa fixed effect model lebih tepat untuk digunakan dibandingkan common effect model.

\subsubsection{Uji Lagrangge Multiplier (LM)}

Uji Lagrangge Multiplier (LM) digunakan untuk memilih apakah common effect model atau random effect model yang lebih tepat digunakan dalam model persamaan regresi data panel.

Tabel 5.8 Uji LM

Lagrange multiplier (LM) test for panel data

Date: 01/05/19 Time: 06:01

Sample: 20132017

Total panel observations: 145

Probability in ()

\begin{tabular}{|c|c|c|c|}
\hline $\begin{array}{l}\text { Null (no rand. effect) } \\
\text { Alternative }\end{array}$ & $\begin{array}{l}\text { Cross-section } \\
\text { One-sided }\end{array}$ & $\begin{array}{l}\text { Period } \\
\text { One-sided }\end{array}$ & Both \\
\hline
\end{tabular}




\begin{tabular}{|llcl|} 
Breusch-Pagan & 7.675903 & 0.633280 & 8.309184 \\
Honda & $(0.0056)$ & $(0.4262)$ & $(0.0039)$ \\
& 2.770542 & -0.795789 & 1.396361 \\
King-Wu & $(0.0028)$ & $(0.7869)$ & $(0.0813)$ \\
& 2.770542 & -0.795789 & 0.235142 \\
GHM & $(0.0028)$ & $(0.7869)$ & $(0.4070)$ \\
& -- & -- & 7.675903 \\
& -- & -- & $(0.0082)$ \\
\hline \hline
\end{tabular}

Sumber: Hasil olahan Eviews 9

Berdasarkan tabel 5.8, dapat

dilihat nilai probabilitas Breusch-Pagan

sebesar 0,0056 yang nilainya $<0,05$.

Maka disimpulkan bahwa Random

Effect Model lebih tepat digunakan daripada model Common Effect Model.

\subsubsection{Uji Hausman}

Uji Hausman dilakukan untuk membandingkan atau memilih model mana yang terbaik antara Fixed Effect model dan Random Effect model.

Tabel 5.9 Uji Hausman

\begin{tabular}{|c|c|c|c|c|}
\hline \multicolumn{5}{|c|}{$\begin{array}{l}\text { Correlated Random Effects - Hausman Test } \\
\text { Pool: KODE_PERUSAHAAN } \\
\text { Test cross-section random effects }\end{array}$} \\
\hline Test Summary & & $\begin{array}{l}\text { Chi-Sq. } \\
\text { Statistic }\end{array}$ & Chi-Sq. d.f. & Prob. \\
\hline Cross-section random & & 2.292899 & 4 & 0.6821 \\
\hline \multicolumn{5}{|c|}{ Cross-section random effects test comparisons: } \\
\hline Variable & Fixed & Random & Var(Diff.) & Prob. \\
\hline $\begin{array}{l}\text { CR? } \\
\text { DER? } \\
\text { SIZE? } \\
\text { GROWTH? }\end{array}$ & $\begin{array}{r}-0.910291 \\
-0.387940 \\
0.555020 \\
4.868730\end{array}$ & $\begin{array}{r}-0.735836 \\
-0.608054 \\
0.508127 \\
4.826272\end{array}$ & $\begin{array}{l}0.042112 \\
0.182773 \\
0.026795 \\
0.009019\end{array}$ & $\begin{array}{l}0.3953 \\
0.6066 \\
0.7745 \\
0.6548\end{array}$ \\
\hline \multicolumn{5}{|c|}{$\begin{array}{l}\text { Cross-section random effects test equatic } \\
\text { Dependent Variable: ROA? } \\
\text { Method: Panel Least Squares } \\
\text { Date: } 02 / 27 / 19 \text { Time: } 20: 25 \\
\text { Sample: } 15 \\
\text { Included observations: } 5 \\
\text { Cross-sections included: } 29 \\
\text { Total pool (balanced) observations: } 145\end{array}$} \\
\hline Variable & Coefficient & Std. Error & t-Statistic & Prob. \\
\hline $\begin{array}{c}\text { C } \\
\text { CR? } \\
\text { DER? } \\
\text { SIZE? } \\
\text { GROWTH? }\end{array}$ & $\begin{array}{r}2.325505 \\
-0.910291 \\
-0.387940 \\
0.555020 \\
4.868730\end{array}$ & $\begin{array}{l}3.884930 \\
0.359557 \\
0.957526 \\
0.319555 \\
0.715707\end{array}$ & $\begin{array}{r}0.598596 \\
-2.531705 \\
-0.405148 \\
1.736853 \\
6.802686\end{array}$ & $\begin{array}{l}0.5507 \\
0.0127 \\
0.6861 \\
0.0852 \\
0.0000\end{array}$ \\
\hline
\end{tabular}




\begin{tabular}{|lrlr|}
\multicolumn{2}{|c|}{ Effects Specification } \\
\hline \hline & & \\
\hline & & \\
& & \\
& & \\
& & & \\
R-squared & 0.644941 & Mean dependent var & 7.041796 \\
Adjusted R-squared & 0.543495 & S.D. dependent var & 5.359785 \\
S.E. of regression & 3.621345 & Akaike info criterion & 5.608506 \\
Sum squared resid & 1468.784 & Schwarz criterion & 6.285969 \\
Log likelihood & -373.6167 & Hannan-Quinn criter. & 5.883782 \\
F-statistic & 6.357514 & Durbin-Watson stat & 1.893442 \\
Prob(F-statistic) & 0.000000 & & \\
\hline \hline
\end{tabular}

\section{Sumber: Hasil Olahan Eviews 9}

Berdasarkan tabel 5.9, dapat dilihat bahwa nilai probabilitas (Prob) Crosssection random sebesar 0,6821 yang nilainya > 0,05. Maka dapat disimpulkan bahwa random effect model lebih tepat digunakan dibandingkan dengan fixed effect model.

\subsection{Hasil Uji Hipotesis}

Penelitian ini menggunakan analisis regresi berganda dalam pengolahan datanya. Analisis ini menggunakan uji simultan (uji F), uji parsial (uji t) dan uji koefisien determinasi (R2) dengan menggunakan tingkat signifikansi sebesar $10 \%$ atau 0,10 . Ketentuan pengujian hipotesis secara parsial, yaitu :

H0 tidak signifikan dan $\mathrm{H} 1$ signifikan Apabila nilai probabilitas $<0,10$ maka $\mathrm{H} 0$ ditolak dan $\mathrm{H} 1$ diterima

Apabila nilai probabilitas $>0,10$ maka $\mathrm{H} 1$ ditolak dan $\mathrm{HO}$ diterima

$$
\begin{aligned}
& \text { 5.2.1 Uji F ( Kelayakan } \\
& \text { Model) }
\end{aligned}
$$$$
\text { Menurut Ghozali (2006) }
$$

mengatakan bahwa Uji statistik F pada dasarnya menunjukkan apakah semua variabel bebas yang dimasukkan dalam model mempunyai pengaruh secara simultan terhadap variabel terikat.

\begin{tabular}{|c|c|c|c|}
\hline \multicolumn{3}{|c|}{ Effects Specification } & Rho \\
\hline $\begin{array}{l}\text { Cross-section random } \\
\text { Idiosyncratic random }\end{array}$ & & $\begin{array}{l}3.509778 \\
3.621345\end{array}$ & $\begin{array}{l}0.4844 \\
0.5156\end{array}$ \\
\hline \multicolumn{4}{|c|}{ Weighted Statistics } \\
\hline $\begin{array}{l}\text { R-squared } \\
\text { Adjusted R-squared } \\
\text { S.E. of regression } \\
\text { F-statistic } \\
\text { Prob(F-statistic) }\end{array}$ & $\begin{array}{l}0.542749 \\
0.282828 \\
3.599199 \\
15.19713 \\
0.000000\end{array}$ & $\begin{array}{l}\text { Mean dependent var } \\
\text { S.D. dependent var } \\
\text { Sum squared resid } \\
\text { Durbin-Watson stat }\end{array}$ & $\begin{array}{l}2.950348 \\
4.250050 \\
1813.592 \\
1.943039\end{array}$ \\
\hline \multicolumn{4}{|c|}{ Unweighted Statistics } \\
\hline $\begin{array}{l}\text { R-squared } \\
\text { Sum squared resid }\end{array}$ & $\begin{array}{l}0.175789 \\
3409.541\end{array}$ & $\begin{array}{l}\text { Mean dependent var } \\
\text { Durbin-Watson stat }\end{array}$ & $\begin{array}{l}7.041796 \\
1.271589\end{array}$ \\
\hline
\end{tabular}

Tabel 5.10 Hasil Uji Simultan Variabel 
Berdasarkan tabel 5.10, dapat dilihat bahwa nilai profitabilitas Fstatistic untuk random effect model sebesar 0.000000 . Dengan tingkat kelayakan $10 \%$ (alpha 0,10) maka $\mathrm{Ha}$ ditolak karena nilai probabilitas $\mathrm{F}<$ 0,05 . Hal ini berarti bahwa variabel independen (likuiditas, Leverage, ukuran perusahaan dan Pertumbuhan penjualan) secara simultan

berpengaruh terhadap tingkat profitabilitas perusahaan.

\subsubsection{Uji Parsial (Uji t)}

Uji statistik $t$ untuk mengukur seberapa jauh pengaruh masing-masing variabel independen dalam menerangkan variabel dependen dengan tingkat signifikansi $10 \%$ atau 0,10 .

\section{Tabel 5.11 Hasil Uji Parsial Variabel}

Dependent Variable: ROA?

Method: Panel EGLS (Cross-section random effects)

Date: 02/27/19 Time: 21:05

Sample: 20132017

Periods included: 5

Cross-sections included: 29

Total panel (balanced) observations: 145

Swamy and Arora estimator of component variances

\begin{tabular}{|c|c|c|c|c|}
\hline Variable & Coefficient & Std. Error & t-Statistic & Prob. \\
\hline $\mathrm{C}$ & 2.621797 & 3.370669 & 0.777827 & 0.4380 \\
\hline CR? & -0.735836 & 0.295244 & -2.492301 & 0.0139 \\
\hline DER? & -0.608054 & 0.856787 & -0.709692 & 0.4791 \\
\hline SIZE? & 0.508127 & 0.274446 & 1.851467 & 0.0662 \\
\hline GROWTH? & 4.826272 & 0.709379 & 6.803521 & 0.0000 \\
\hline \multicolumn{5}{|c|}{ Effects Specification } \\
\hline & & & S.D. & Rho \\
\hline Cross-section random & & & 3.509778 & 0.4844 \\
\hline Idiosyncratic random & & & 3.621345 & 0.5156 \\
\hline \multicolumn{5}{|c|}{ Weighted Statistics } \\
\hline R-squared & 0.542749 & \multirow{5}{*}{\multicolumn{2}{|c|}{$\begin{array}{l}\text { Mean dependent var } \\
\text { S.D. dependent var } \\
\text { Sum squared resid } \\
\text { Durbin-Watson stat }\end{array}$}} & 2.950348 \\
\hline Adjusted R-squared & 0.282828 & & & 4.250050 \\
\hline S.E. of regression & 3.599199 & & & 1813.592 \\
\hline F-statistic & 15.19713 & & & 1.943039 \\
\hline Prob(F-statistic) & 0.000000 & & & \\
\hline \multicolumn{5}{|c|}{ Unweighted Statistics } \\
\hline R-squared & 0.175789 & \multirow{2}{*}{\multicolumn{2}{|c|}{ Mean dependent var }} & 7.041796 \\
\hline Sum squared resid & 3409.541 & & Durbin-Watson stat & 1.271589 \\
\hline
\end{tabular}

\section{Sumber: Hasil Olahan Eviews 9}

Berdasarkan tabel 5.9 dapat

disimpulkan bahwa :

a. Variabel likuiditas (X1) memiliki pengaruh negatif dan signifikan terhadap profitabilitas yang dimiliki perusahaan. Hal ini ditunjukkan dengan nilai coefficient current ratio (CR) sebesar -0.735836 dan nilai probabilitas t-statistik untuk variabel current ratio sebesar 0.0139. Dimana pada tingkat signifikan $10 \%$, nilai probabilitas tersebut $<0,10$. Maka $\mathrm{HO}$ ditolak dan $\mathrm{H} 1$ diterima. 
b. Variabel leverage (X2) memiliki pengaruh negatif dan tidak signifikan terhadap profitabilitas yang dimiliki perusahaan. Hal ini ditunjukkan dengan nilai coefficient debt to equity ratio (DER) sebesar -0.608054 dan nilai probabilitas t-statistik untuk variabel debt to equity ratio sebesar 0.4791. Dimana pada tingkat signifikan $10 \%$, nilai probabilitas tersebut $>0,10$. Maka H1 ditolak dan H0 diterima

c. Variabel ukuran perusahaan (X3) memiliki pengaruh positif dan signifikan terhadap profitabilitas yang dimiliki perusahaan. Hal ini ditunjukkan dengan nilai coefficient ukuran perusahaan (size) sebesar 0.508127 dan nilai probabilitas tstatistik untuk variabel size sebesar 0.0662. Dimana pada tingkat signifikan $10 \%$, nilai probabilitas tersebut $<0,10$. Maka H0 ditolak dan H1 diterima.

d. Variabel pertumbuhan penjualan (X4) memiliki pengaruh positif dan signifikan terhadap profitabilitas yang dimiliki perusahaan. Hal ini ditunjukkan dengan nilai coefficient pertumbuhan penjualan (growth) sebesar 4.826272 dan nilai probabilitas t-statistik untuk variabel growth sebesar 0.0000 . Dimana pada tingkat signifikan $10 \%$, nilai probabilitas tersebut $<$ 0,10. Maka $\mathrm{HO}$ ditolak dan $\mathrm{H} 1$ diterima.

\subsubsection{Uji koefisien}

determinasi $\left(\mathbf{R}^{2}\right)$

Uji koefisien determinasi $\left(R^{2}\right)$ digunakan untuk mengukur seberapa jauh kemampuan model dalam menerangkan variasi variabel dependen. Nilai koefisien determinasi antara 0 dan 1. Apabila nilai koefisien determinasi mendekati satu, maka variabel independen memberikan hampir semua informasi yang dibutuhkan dalam memprediksi variabel dependen. Penelitian ini menggunakan koefisien determinasi dengan menggunakan nilai R-square untuk mengevaluasi model regresi. Nilai $R$-squared dalam penelitian dapat dilihat dalam tabel 5.12 di bawah ini :

Tabel 5.12 Hasil Uji Koefisien Determinasi

\begin{tabular}{|c|c|c|c|}
\hline \multicolumn{4}{|c|}{ Effects Specification } \\
\hline $\begin{array}{l}\text { Cross-section random } \\
\text { Idiosyncratic random }\end{array}$ & & $\begin{array}{l}3.509778 \\
3.621345\end{array}$ & $\begin{array}{l}0.4844 \\
0.5156\end{array}$ \\
\hline \multicolumn{4}{|c|}{ Weighted Statistics } \\
\hline $\begin{array}{l}\text { R-squared } \\
\text { Adjusted R-squared } \\
\text { S.E. of regression } \\
\text { F-statistic } \\
\text { Prob(F-statistic) }\end{array}$ & $\begin{array}{l}0.542749 \\
0.282828 \\
3.599199 \\
15.19713 \\
0.000000\end{array}$ & $\begin{array}{l}\text { Mean dependent var } \\
\text { S.D. dependent var } \\
\text { Sum squared resid } \\
\text { Durbin-Watson stat }\end{array}$ & $\begin{array}{l}2.950348 \\
4.250050 \\
1813.592 \\
1.943039\end{array}$ \\
\hline & Unweightec & Statistics & \\
\hline
\end{tabular}




\section{Sumber: Hasil olahan Eviews 9}

Berdasarkan tabel 5.12, hasil pengujian menggunakan random effect model profitabilitas pada perusahaan Property dan Real Estate yang terdaftar di BEl diperoleh $R$-squared $\left(R^{2}\right)$ sebesar 0.542749. Artinya variabel bebas (likuiditas, leverage, ukuran perusahaan dan pertumbuhan penjualan) yang ada dalam model dapat menjelaskan profitabilitas sebesar $54 \%$ sedangkan sisanya sebesar $46 \%(100 \%$ - $54 \%)$ sisanya dijelaskan oleh variabel lain diluar model.

Tabel 5.13 Hasil Estimasi dengan Random Effect Model

\begin{tabular}{|c|c|c|c|c|}
\hline \multicolumn{5}{|c|}{$\begin{array}{l}\text { Dependent Variable: ROA? } \\
\text { Method: Panel EGLS (Cross-section random effects) } \\
\text { Date: } 02 / 27 / 19 \text { Time: } 21: 05 \\
\text { Sample: } 20132017 \\
\text { Periods included: } 5 \\
\text { Cross-sections included: } 29 \\
\text { Total panel (balanced) observations: } 145 \\
\text { Swamy and Arora estimator of component variances }\end{array}$} \\
\hline Variable & Coefficient & Std. Error & t-Statistic & Prob. \\
\hline $\begin{array}{c}\text { C } \\
\text { CR? } \\
\text { DER? } \\
\text { SIZE? } \\
\text { GROWTH? }\end{array}$ & $\begin{array}{r}2.621797 \\
-0.735836 \\
-0.608054 \\
0.508127 \\
4.826272\end{array}$ & $\begin{array}{l}3.370669 \\
0.295244 \\
0.856787 \\
0.274446 \\
0.709379\end{array}$ & $\begin{array}{r}0.777827 \\
-2.492301 \\
-0.709692 \\
1.851467 \\
6.803521\end{array}$ & $\begin{array}{l}0.4380 \\
0.0139 \\
0.4791 \\
0.0662 \\
0.0000\end{array}$ \\
\hline \multicolumn{5}{|c|}{ Effects Specification } \\
\hline $\begin{array}{l}\text { Cross-section random } \\
\text { Idiosyncratic random }\end{array}$ & & & $\begin{array}{l}3.509778 \\
3.621345\end{array}$ & $\begin{array}{l}0.4844 \\
0.5156\end{array}$ \\
\hline \multicolumn{5}{|c|}{ Weighted Statistics } \\
\hline $\begin{array}{l}\text { R-squared } \\
\text { Adjusted R-squared } \\
\text { S.E. of regression } \\
\text { F-statistic } \\
\text { Prob(F-statistic) }\end{array}$ & $\begin{array}{l}0.542749 \\
0.282828 \\
3.599199 \\
15.19713 \\
0.000000\end{array}$ & $\begin{array}{l}\text { Mean depen } \\
\text { S.D. depend } \\
\text { Sum squared } \\
\text { Durbin-Wats }\end{array}$ & $\begin{array}{l}\text { It var } \\
\text { var } \\
\text { sid } \\
\text { stat }\end{array}$ & $\begin{array}{l}2.950348 \\
4.250050 \\
1813.592 \\
1.943039\end{array}$ \\
\hline \multicolumn{5}{|c|}{ Unweighted Statistics } \\
\hline $\begin{array}{l}\text { R-squared } \\
\text { Sum squared resid }\end{array}$ & $\begin{array}{l}0.175789 \\
3409.541\end{array}$ & $\begin{array}{l}\text { Mean depenc } \\
\text { Durbin-Watsc }\end{array}$ & $\begin{array}{l}\text { it var } \\
\text { stat }\end{array}$ & $\begin{array}{l}7.041796 \\
1.271589\end{array}$ \\
\hline
\end{tabular}

\section{Sumber: Hasil Olahan Eviews 9}


Berdasarkan tabel diatas persamaan regresi yang dibentuk dalam penelitian ini adalah sebagai berikut :

Profitabilitas $=2.621797-0.735836$

CR - 0.608054 DER + 0.508127 Size + 4.826272 Growth

\subsection{Pembahasan}

Hasil probabilitas dari tstatistik (t-test) yang menguji tingkat signifikansi dari setiap variabel independen. Bahwa pada tingkat signifikan $10 \%$ variabel likuiditas dan pertumbuhan penjualan memiliki pengaruh signifikan terhadap variabel independen (profitabilitas).

Hasil probabilitas F-statistik menunjukkan bahwa secara bersamasama koefisien regresi memiliki nilai yang signifikan. Artinya, variabelvariabel independen secara bersamasama memiliki pengaruh terhadap variabel dependen. Sehingga dapat dikatakan juga bahwa model yang digunakan cukup baik.

Nilai R-squared memiliki nilai 0.542749 yang menunjukkan bahwa tingkat determinasi dari variabel dependen terhadap variabel independen adalah sebesar $54 \%$. Berikut ini adalah perbandingan model untuk profitabilitas yang dihasilkan melalui regresi dengan hipotesis awal :

\section{(F-test) memiliki 0,00000 yang}

Tabel 5.14 Perbandingan Model Untuk Profitabilitas yang dihasilkan Melalui Regresi Dengan Hipotesis Awal

\begin{tabular}{|l|r|r|c|c|}
\hline Variabel & \multirow{2}{*}{$\begin{array}{c}\text { Coeficie } \\
\text { nt }\end{array}$} & Prob. & $\begin{array}{c}\text { Hipotesis } \\
\text { Awal }\end{array}$ & Tanda Koefisien \\
\hline CR & 0.007358 & 0.0139 & Negatif & Negatif \\
\hline DER & 0.006081 & 0.4791 & Negatif & Negatif \\
\hline SIZE & 0.005081 & 0.0662 & Positif & Positif \\
\hline $\begin{array}{c}\text { GROWT } \\
\text { H }\end{array}$ & 0.048263 & 0.0000 & Positif & Positif \\
\hline
\end{tabular}

Sumber : Hasil Olahan Eviews 9

${ }^{* *}$ Signifikan 0,10

Model penelitian untuk analisis profitabilitas yang digunakan adalah Random Effect Model, hal ini memberikan tingkat determinasi $\mathrm{R}^{2}$ sebesar $54 \%$. Sehingga validitas profitabilitas dapat dijelaskan oleh variabel-variabel independen $54 \%$. Melalui model ini juga dihasilkan Fstatistik 0,000000 yang menunjukkan bahwa secara bersama-sama variabel independen berpengaruh terhadap variabel dependen. Sedangkan untuk hasil t-statistik akan dijelaskan sebagai berikut.

\subsection{1}

Pengaruh Likuiditas
terhadap Profitabilitas
Berdasarkan hasil analisis
pengaruh likuiditas terhadap profitabilitas perusahaan Property dan Real Estate, variabel memberikan hasil estimasi tanda koefisien yang positif sesuai dengan hipotesis awal yaitu diterima. Hasil uji t-test pada tabel 5.11 menunjukkan bahwa variabel likuiditas memiliki pengaruh yang negatif dan signifikan terhadap profitabilitas. Maka hipotesis penelitian yang menyatakan bahwa likuiditas memiliki pengaruh positif dan signifikan terhadap profitabilitas perusahaan cukup bukti untuk diterima.

Tanda koefisien negatif menunjukkan bahwa semakin tinggi current ratio (CR) akan mengurangi kemampuan perusahaan untuk menghasilkan laba, begitupun sebaliknya. Penelitian ini sejalan dengan pernyataan Horne bahwa likuiditas berbanding terbalik dengan profitabilitas, artinya semakin tinggi likuiditas maka kemampuan perusahaan untuk menghasilkan 
keuntungan atau laba perusahaan akan semakin rendah.

Hal ini terjadi karena perusahaan telah menggunakan sebagian besar dananya untuk melunasi kewajiban jangka pendeknya atau likuiditasnya daripada digunakan untuk investasi yang dapat digunakan untuk menghasilkan keuntungan kembali bagi perusahaan. Disisi lain, ditinjau dari sudut pandang pemegang saham, likuiditas yang tinggi tidak selalu menguntungkan karena berpeluang menimbulkan dana-dana yang menganggur yang sebenarnya dapat digunakan untuk proyek-proyek yang menguntungkan perusahaan Property dan Real Estate.

Semakin besar tingkat aset lancar semakin besar juga likuiditas perusahaan, jika hal-hal lainnya sama. Dengan likuditas yang lebih besar, risiko semakin kecil, namun profitabilitas juga semakin kecil. Hal ini menunjukkan perusahaan melakukan penempatan dana yang besar pada sisi aktiva lancar. Penempatan dana yang besar pada sisi aktiva memiliki dua efek yang berlainan. Di satu sisi, likuiditas perusahaan semakin baik. Namun disisi lain, perusahaan kehilangan kesempatan untuk mendapatkan tambahan laba, karena dana yang seharusnya digunakan untuk investasi yang menguntungkan, dicadangkan untuk memenuhi likuiditasnya

Perusahaan yang memiliki likuiditas tinggi merupakan perusahaan yang memiliki jumlah aktiva lancar lebih banyak daripada hutang lancarnya. Apabila jumlah aktiva lancar ini terlalu banyak, itu artinya terdapat sebagian modal kerja perusahaan tidak berputar atau mengalami penganguran (iddle cash) sehingga akan berpengaruh terhadap menurunnya kemampuan perusahaan dalam memperoleh laba.

$$
\text { Hasil penelitian ini }
$$

mendukung penelitian yang telah dilakukan oleh Novi Sagita et.,al
(2015), yang menunjukkan bahwa likuiditas memiliki pengaruh negatif terhadap profitabilitas. Sehingga hipotesis 1 yang menyatakan likuiditas berpengaruh negatif dan signifikan terhadap profitabilitas diterima.

\subsubsection{Pengaruh terhadap Profitabilitas}

Berdasarkan hasil analisis

pengaruh leverage terhadap profitabilitas perusahaan Property dan Real Estate, variabel memberikan hasil estimasi tanda koefisien yang negatif sesuai dengan hipotesis awal yaitu diterima. Hasil uji t-test pada tabel 5.11 menunjukkan bahwa variabel leverage memiliki pengaruh yang negatif dan tidak signifikan terhadap profitabilitas. Maka hipotesis penelitian yang menyatakan bahwa leverage memiliki pengaruh negatif dan signifikan terhadap profitabilitas perusahaan tidak cukup bukti untuk diterima.

Tanda koefisien negatif menunjukkan adanya hubungan negatif antara leverage dan profitabilitas. hal ini berarti semakin tinggi penggunaan utang akan mengurangi kemampuan perusahaan untuk menghasilkan keuntungan. Keadaan ini mengharuskan pihak manajemen perusahaan perlu meningkatkan prinsip kehati-hatian dalam mengggunakan hutang untuk menghasilkan keuntungan.

Hasil penelitian ini sesuai dengan Pecking Order Theory yang menyatakan bahwa semakin besar penggunaan utang, menunjukkan bahwa semakin besar biaya yang harus ditanggung perusahaan untuk memenuhi kewajiban yang dimilikinya sehingga dapat menurunkan profitabilitas yang dimiliki perusahaan. Hal ini disebabkan karena penggunaan utang yang relatif tinggi akan menimbulkan biaya tetap berupa beban bunga dan angsuran pokok pinjaman yang harus dibayar, yang semakin besar biaya tetap dapat berakibat 
menurutnya laba perusahaan (Halim, 2015).

Pengaruh tidak signifikan ini menunjukkan bahwa di sisi lain, tingginya rasio debt to equity ratio mengindikasikan adanya dana besar dari sumber hutang yang dapat dimanfaatkan dalam operasional perusahaan dalam meningkatkan profitabilitas. Perusahaan yang mendanai assetnya dengan hutang, profitabilitasnya akan menurun karena perusahaan harus memenuhi beban yang harus dibayar dari penggunaan hutang tersebut (bunga). Selain itu, perusahaan memiliki risiko keuangan yang tinggi karena perusahaan terlalu banyak melakukan pendanaan aktiva dari hutang. Seperti adanya risiko gagal bayar, maka biaya yang harus dikeluarkan oleh perusahaan untuk mengatasi masalah ini semakin besar. Hasil penelitian ini mendukung penelitian yang telah dilakukan oleh Nawaf et.,al (2015), Wela Yulia Putra et., al (2015), Rudin M et.,al (2016) dan Usman Ali et.,al (2018), menunjukkan bahwa leverage memiliki pengaruh negatif terhadap profitabilitas. Sehingga hipotesis 2 yang menyatakan leverage berpengaruh negatif dan signifikan terhadap profitabilitas ditolak.

\subsubsection{Pengaruh \\ Perusahaan \\ Profitabilitas \\ Berdasarkan hasil analisis} pengaruh ukuran perusahaan terhadap profutabilitas perusahaan Property dan Real Estate, variabel memberikan hasil estimasi tanda koefisien yang positif sesuai dengan hipotesis awal yaitu diterima. Hasil uji t-test pada tabel 5.11 menunjukkan bahwa variabel ukuran perusahaan memiliki pengaruh yang positif dan signifikan terhadap profitabilitas. Maka hipotesis penelitian yang menyatakan bahwa ukuran perusahaan memiliki pengaruh positif dan signifikan terhadap profitabilitas perusahaan cukup bukti untuk diterima.

Hal ini menunjukkan dengan adanya hubungan positif antara ukuran perusahaan dengan profitabilitas maka semakin besar ukuran perusahaan maka, kemampuan perusahaan dalam menghasilkan profit atau laba dalam perusahaan akan semakin meningkat, begitu pula sebaliknya. Hal ini sejalan dengan critical resources theory yang menyatakan bahwa semakin besar skala perusahaan maka profitabilitas juga akan semakin meningkat, tetapi pada jumlah tertentu ukuran perusahaan akan menurunkan laba (profit) perusahaan.

Pengaruh signifikan ini menunjukkan bahwa perusahaan dengan aset yang besar maka penggunaan sumber daya yang ada bisa digunakan secara maksimal dan efisien untuk memperoleh keuntungan usaha yang maksimal dan perusahaan dengan aset yang kecil tentu akan menghasilkan keuntungan sesuai dengan aset yang relatif kecil. selain itu jika jumlah aset yang dimiliki oleh perusahaan besar maka akan menunjukkan kualitas serta kinerja yang baik dari perusahaan tersebut. Semakin besar aktivitas yang dimiliki perusahaan menunjukkan semakin tinggi profit yang dihasilkan.

Semakin besar ukuran dari perusahaan merupakan sinyal positif, menyebabkan nilai perusahaan semakin tinggi pula. Hal ini disebabkan karena perusahaan yang besar cenderung memiliki kondisi yang lebih stabil. Kondisi tersebut menjadi penyebab atas naiknya harga saham perusahaan di pasar modal karena investor memiliki ekspektasi yang besar terhadap perusahaan besar (Meidiyustiani, 2016 : 167). Peningkatan permintaan saham perusahaan akan dapat memacu pada peningkatan harga saham di pasar modal. Peningkatan tersebut menunjukkan bahwa perusahaan 
dianggap memiliki "nilai" yang lebih besar yang pada akhirnya akan meningkatkan keuntungan dari perusahaan

Hasil penelitian ini mendukung penelitian yang telah dilakukan oleh Andreani et.,al (2013), Asif lqbal et.,al (2015), Novi Sagita et.,al (2015), Dian et.,al (2016) dan Usman Ali et.,al (2018) menunjukkan bahwa ukuran perusahaan memiliki pengaruh positif terhadap profitabilitas. Sehingga hipotesis 3 yang menyatakan ukuran perusahaan berpengaruh positif dan signifikan terhadap profitabilitas diterima.

\subsubsection{Pengaruh Pertumbuhan Penjualan terhadap Profitabilitas \\ Berdasarkan hasil analisis} pengaruh pertumbuhan penjualan terhadap profutabilitas perusahaan Property dan Real Estate, variabel memberikan hasil estimasi tanda koefisien yang positif sesuai dengan hipotesis awal yaitu diterima. Hasil uji ttest pada tabel 5.11 menunjukkan bahwa variabel pertumbuhan penjualan memiliki pengaruh yang positif dan signifikan terhadap profitabilitas. Maka hipotesis penelitian yang menyatakan bahwa pertumbuhan penjualan memiliki pengaruh positif dan signifikan terhadap profitabilitas perusahaan cukup bukti untuk diterima.

Hal ini menunjukkan bahwa dengan adanya hubungan positif antara pertumbuhan penjualan dengan profitabilitas maka semakin besar tingkat pertumbuhan penjualan yang ada di perusahaan Property dan Real Estate maka semakin meningkatkan kemampuan perusahaan dalam menghasilkan profit atau laba dalam perusahaan, begitupun sebaliknya.

Hal ini sejalan dengan pendapat Van Horne yang telah dialihbahasakan oleh Dewi Fitriasari dan Deny Arnos Kwary (2009:321) yang menyatakan bahwa bila penjualan ditingkatkan, maka aktiva pun harus ditambah sedangkan di sisi lain, jika perusahaan tahu dengan pasti permintaan penjualannya di masa mendatang, hasil dari tagihan piutangnya, serta jadwal produknya, perusahaan akan dapat mengatur jadwal jatuh tempo utangnya agar sesuai dengan arus kas bersih di masa mendatang. Akibatnya, laba akan dapat dimaksimalkan.

Dari pernyataan tersebut dapat disimpulkan bahwa, pertumbuhan penjualan dapat meningkatkan keuntungan perusahaan. Selain itu, jika perusahaan dapat mengestimasi tingkat permintaan penjualan di masa mendatang dan mengalokasikan pembayaran utangnya, maka perusahaan akan mendapatkan laba yang maksimal.

Hasil penelitian ini mendukung penelitian yang telah dilakukan oleh Asif Iqbal et.al (2015), Nawaf et.,al (2015) dan Usman Ali et., al (2018) yang menunjukkan bahwa pertumbuhan penjualan memiliki pengaruh positif dan signifikan terhadap profitabilitas. Sehingga hipotesis 4 yang menyatakan pertumbuhan penjualan berpengaruh positif dan signifikan terhadap profitabilitas diterima.

\section{KESIMPULAN DAN SARAN}

\subsection{Kesimpulan}

Penelitian ini bertujuan untuk menguji signifikansi pengaruh likuiditas yang diproksikan dengan current ratio (CR), leverage yang diproksikan dengan debt to equity ratio (DER), ukuran perusahaan dan pertumbuhan penjualan terhadap profitabilitas yang diproksikan dengan return on asset (ROA) pada perusahaan Property dan Real Estate yang terdaftar di Bursa Efek Indonesia tahun 2013-2017.

Berdasarkan hasil analisis penelitian dan pembahasan terkait 
pengaruh likuiditas, leverage, ukuran perusahaan dan pertumbuhan penjualan terhadap profitabilitas perusahaan dengan memasukan variabel $C R$, DER, ukuran perusahaan dan pertumbuhan penjualan sebagai variabel independen dan ROA sebagai variabel dependen dalam penelitian. Sehingga, dapat ditarik kesimpulan sebagai berikut :

a. Variabel likuiditas (X1) mempunyai pengaruh negatif dan signifikan terhadap profitabilitas yang dimiliki perusahaan. Hal ini menunjukkan bahwa likuiditas tidak mampu meningkatkan profitabilitas. Artinya, semakin besar likuiditas perusahaan maka kemampuan perusahaan untuk menghasilkan laba akan menurun. Hal ini terjadi karena karena adanya dana-dana yang menganggur yang sebenarnya dapat digunakan untuk proyekproyek yang menguntungkan perusahaan.

b. Variabel leverage (X2) mempunyai pengaruh negatif dan tidak signifikan terhadap profitabilitas yang dimiliki perusahaan. Artinya, semakin besar penggunaan utang oleh perusahaan maka kemampuan perusahaaan untuk menghasilkan laba akan menurun. Hasil ini sesuai dengan Pecking Order Theory yang menyatakan bahwa semakin besar penggunaan utang, menunjukkan bahwa semakin besar biaya yang harus ditanggung perusahaan untuk memenuhi kewajiban yang dimilikinya sehingga dapat menurunkan profitabilitas yang dimiliki perusahaan.

c. Variabel ukuran perusahaan (X3) mempunyai pengaruh positif dan signifikan terhadap profitabilitas yang dimiliki perusahaan. Artinya, semakin besar ukuran perusahaan maka semakin meningkatkan kemampuan perusahaan dalam menghasilkan profit atau laba dalam perusahaan. Hal ini sejalan dengan critical resources theory yang menyatakan bahwa semakin besar skala perusahaan maka profitabilitas juga akan semakin meningkat, tetapi pada jumlah tertentu ukuran perusahaan akan menurunkan laba (profit) perusahaan.

d. Variabel pertumbuhan penjualan (X4) mempunyai pengaruh positif dan signifikan terhadap profitabilitas yang dimiliki perusahaan. Artinya, semakin besar pertumbuhan penjualan maka semakin meningkatkan kemampuan perusahaan dalam menghasilkan profit atau laba dalam perusahaan.

\subsection{Keterbatasan Penelitian}

Dalam penelitian ini masih terdapat keterbatasan-keterbatasan yang dapat dijadikan bahan pertimbangan bagi penelitian selanjutnya agar mampu mendapatkan hasil yang lebih baik, antara lain :

1. Penelitian ini hanya menggunakan perusahaan Property dan Real Estate yang go publik yang terdaftar di BEl sebagai sampel.

2. Masih adanya variabel lain yang belum digunakan pada penelitian yang dapat mempengaruhi profitabilitas pada perusahaan Property dan Real Estate yang terdaftar di BEI.

\subsection{Saran}

Berdasarkan kesimpulan dan keterbatasan penelitian maka saran yang dapat diajukan dalam penelitian ini adalah sebagai berikut: 
1. Bagi Pihak Investor

Adapun saran yang dapat saya

berikan kepada investor yang berinvestasi dipasar modal terkait dengan penelitian saya adalah kondisi likuiditas, leverage, ukuran perusahaan dan pertumbuhan pejualan dalam perusahaan sampel dapat dijadikan informasi mengenai investasi yang akan dilakukan oleh para investor.

2. Bagi Pihak Manajemen

Perusahaan

Adapun saran yang dapat saya berikan kepada pihak manajemen perusahaan terkait dengan penelitian saya adalah dapat dijadikan acuan bagi pihak perusahaan untuk bahan mebuat kebijakan strategis, sehingga optimalisasi profit perusahaan yang merupakan tujuan perusahaan dapat tercapai. Selain untuk meningkatkan kemakmuran pemegang saham, juga untuk menjaga kelangsungan hidup perusahaan.

3. Bagi Peneliti Selanjutnya

Adapun saran yang dapat saya berikan kepada peneliti selanjutnya yaitu:

a. Pengukuran variabel likuiditas dalam penelitian ini adalah menggunakan current ratio (CR). Bagi peneliti selanjutnya dapat menggunakan pengukuran lain selain current ratio (CR).

b. Pengukuran variabel leverage dalam penelitian ini adalah menggunakan debt to equity ratio (DER). Bagi peneliti selanjutnya dapat menggunakan pengukuran lain selain debt to equity ratio (DER).

c. Pengukuran variabel ukuran perusahaan dalam penelitian ini adalah menggunakan Logarithm naturat (Ln) Total Assets. Bagi peneliti selanjutnya dapat menggunakan pengukuran lain selain Logarithm naturat (Ln) Total Assets. d. Pengukuran variabel pertumbuhan penjualan dalam penelitian ini adalah menggunakan growth. Bagi peneliti selanjutnya dapat menggunakan pengukuran lain selain tingkat pertumbuhan penjualan.

e. Pengukuran variabel profitabilitas dalam penelitian ini adalah menggunakan return on asset (ROA). Bagi peneliti selanjutnya dapat menggunakan pengukuran lain selain return on asset (ROA).

f. Peneliti selanjutnya diharapkan dapat menambah jumlah sampel dan waktu pengamatan yang digunakan agar sampel yang diteliti lebih banyak, serta menambahkan variabel market share, inflasi, suku bunga, dan variabel lain selain variabel yang diteliti dalam penelitian yang dapat mempengaruhi profitabilitas agar mendapatkan hasil yang lebih akurat.

\section{DAFTAR PUSTAKA}

Agca, S. \& Mozumdar, A.(2003). Firm size, debt capacity, and the pecking order theory of financing choices,. Working Paper, Virginia Tech.

Ali, Usman, Lida Ormal dan Faizan Ahmad. 2018. Impact of Free Cash Flow on Profitability of the Firms in Automobile Sector of Germany. Journal of Economics and Management Sciences, Vol. 1, Issue 1

Andrayani, Ni Putu Devi. 2013. Pengaruh Pertumbuhan Penjualan, Ukuran Perusahaan, dan Tangibility Assets Terhadap Struktur Modal. Skripsi. Sarjana Jurusan Manajemen Fakultas Ekonomi dan Bisnis Universitas Udayana Bali.

Ardiansyah, Edo Fani dan Linda Purnama Sari. 2017. The effect of 
leverage, liquidity, and size of company on profitability in mining companies listed on Indonesia Stock Exchange.

Atmadja, Adwin S. 1999. Inflasi Di Indonesia: Sumber-sumber Penyebab Dan Pengendaliannya. Surabaya.

Ba-Abbad, Khaled and Nurwati Ashikkin Ahmad-Zaluki. 2012. The Determinants of Capital Structure of Qatari Listed Companies. International Journal of Academic Research in Accounting, Finance and Management Science, 2 (2), pp: 93-108.

Barus, Andreani Caroline dan Leliani. 2013. Analisis Faktor-Faktor yang Mempengaruhi Profitabilitas pada Perusahaan Manufaktur yang Terdaftar di Bursa Efek Indonesia. Jurnal Wira Ekonomi Mikroskil, Vol.3, No.2, Hal:111-121.

Brigham, Eugene $F$. dan Joel $F$. Houston. 2010. Dasar-Dasar Manajemen Keuangan. Buku 2 edisi 11. Jakarta : Salemba Empat.

DiPietre, D., et al. 2007. Critical Control Points: Managing Assets, Expenses and Leverage. http://www.ansc.purdue.edu/swine/ sw ineday/sday $97 / 8$.pdf.

Fabozzi, J. Frank. 2000. Manajemen Investasi. Alih Bahasa: Tim Alih Bahasa Salemba Empat. Buku 2. Jakarta: Salemba Empat.

Fahmi, Irham. 2013. Pengantar Manajemen Keuangan. Cetakan Kedua. Bandung : Alfabeta.

Fama, F. \& French, R. (2004). Financing decisions: Who issues stock, Journal of Financial Economics, 1(2); 1-5

Frank, Z. \& Goyal, K. (2003). Testing the pecking order theory of capital structure,. Journal of Financial Economics, 67, 217-248.

Ghozali, Imam. 2011. Aplikasi Analisis Multivariate dengan Program
SPSS. Semarang: Badan Penerbit Universitas Diponegoro.

Halim, Abdul. 2015. Manajemen Keuangan Bisnis : Konsep dan Aplikasinya. Edisi Pertama. Jakarta : Mitra Wacana Media.

Harahap, Sofyan Syafri. 2013. Analitis Kritis Atas Laporan Keuangan. Edisi 11. Jakarta: PT Raja Grafindo Persada

Harmono, (2009). Manajemen Keuangan. Cetakan Pertama. Jakarta: Bumi Aksara.

Hery. 2015. Analisis Laporan Keuangan. Jakarta : Penerbit CAPS.

Husnan, Saud. 1998. Dasar-dasar Teori Portofolio \& Analisis Sekuritas. Yogyakarta : UPP AMP YKPN.

2015. Dasar-Dasar Manajemen Keuangan, Edisi Ketujuh. Yogyakarta: UPP STIM YKPN.

Iqbal, Asif dan Wang Zhuquan. 2015. Working Capital Management and Profitability Evidence from Firms Listed on Karachi Stock Exchange. International Journal of Business and Management; Vol. 10, No. 2.

Iskandar. 2008. Metode Penelitian Pendidikan dan Sosial (Kualitatif dan Kuantitatif). Jakarta: Gaung Persada.

Jusuf, Jopie. 2014. Analisis Kredit. Jakarta : PT.Gramedia Pustaka Utama.

Kasmir. 2010. Pengantar Manajemen Keuangan. Edisi Pertama, Cetakan Kedua, Jakarta : Kencana. 2012. Analisis Laporan Keuangan. Edisi Pertama. Cetakan keenam. Jakarta : PT.Raja Grafindo Persada.

Kennedy, Nur Azlina dan Anisa Ratna Suzana. 2013. Faktor-Faktor yang Mempengaruhi Struktur Modal pada Perusahaan Real Estate and Property yang Go Public di Bursa Efek Indonesia. Jurnal Akuntasi, $\mathrm{h}: 1-10$. 
Khumairoh, Novida Dwi, Yudhanta Sambharakreshna dan Nurul Kompyurini. 2014. influence of quality of Good Corporate Governance on firm value with financial performance as intervening variables, and effectiveness of Good Corporate Governance influence either directly or indirectly to the firm value. JAFFA Vol. 02 No. 1 April 2014 Hal. 51 - 60.

Kouser, Rehana, Tahira Bano, Muhammad Azeen and Masood-ulHassan. 2012. Inter-Relationship between Profitability, Growth and Size: A Case of NonFinancial Companies from Pakistan. Pak.J.Commer.Soc.Sci, 6 (2), pp: 405- 419.

Lundholm, Russell dan Richard Sloan. 2007. Equity Valuation and Analysis. Second Edition. Singapore: McGraw-Hill.

M. Hanafi, Mamduh dan Abdul Halim. 2009. Analisis Laporan Keuangan. Yogyakarta: UPP STIM YKPN.

Mansuri. (2016). MODUL PRAKTIKUM EVIEWS 9. Modul Praktikum Eviews 9.

Meidiyustiani, Rinny. 2016. Pengaruh Modal Kerja, Ukuran Perusahaan, Pertumbuhan Penjualan dan Likuiditas Terhadap Profitabilitas pada Perusahaan Manufaktur Sektor Industri Barang Konsumsi yang Terdaftar di Bursa Efek Indonesia (BEI) Periode Tahun 2010 - 2014. Jurnal Akuntansi dan Keuangan. Vol. 5. No.2. Oktober.

Munawir, 2007. Analisis Laporan Keuangan. Edisi 4. Liberty. Yogyakarta.

Najmudin. 2011. Manajemen Keuangan dan Aktualisasi Syar'iyyah Modern. Yogyakarta : Penerbit Andi.

Nawaf. 2015. The Impact of Financial Leverage, Growth, and Size on Profitability of Jordanian Industrial Listed Companies. Research
Journal of Finance and Accounting. ISSN 2222-1697 (Paper), ISSN 2222-2847 (Online), Vol.6, No.16, 2015

Ni Gst. A. Pt. Silka Prastika. 2013. Pengaruh IOS, Leverage, dan Dividen Yield terhadap Profitabilitas dan Niai Perusahaan sektor Manufaktur di BEI. Jurnal Ekonomi dan Bisnis. Vol.2, No.3, 2013, Hal:147-158.

Neuman, W.L. (2007). Basic of social research: Qualitative and Quantitative approaches (2nd ed). Boston: Pearson International Edition.

Novi Sagita Ambarwati, Gede Adi Yunitara, Ni Kadek Sinarwati. 2015. Pengaruh Modal Kerja, Likuiditas, Aktivitas dan Ukuran perusahaan terhadap Profitabilitas. Jurnal IImiah Akuntansi, Vol. 3, No. 1, 2015.

Nugroho, Elfianto. 2011. Analisis Pengaruh Likuiditas, Pertumbuhan Penjualan, Perputaran Modal Kerja, Ukuran Perusahaan dan Leverage Terhadap Profitabilitas Perusahaan. Jurnal Ekonomi Vol.1 No.7. Universitas Diponegoro.

Pagano, P. and F. Schivardi. 2003. Firm Size Distribution and Growth. Scandinavian Journal of Economics, 105(2), pp: 255-274.

Putra, A.A Wela Yulia dan Ida bagus Badjra. 2015. Pengaruh Leverage, Pertumbuhan Penjualan dan Ukuran perusahaan Terhadap Profitabilitas. E-Jurnal Manajemen Unud, Vol. 4, No. 7

Rifai. M., R. Arifati dan M. Magdalena, (2013). Pengaruh Ukuran Perusahaan, Struktur Modal dan Pertumbuhan Perusahaan Terhadap Profitabilitas. Jurnal Akuntansi Universitas Pandanaran Semarang, Vol. 2, No. 1, pp: 768783.

Ritonga, M. Rahayu, S.M. dan Kertahadi, (2014). Pengaruh 
Financial Leverage terhadap Profitabilitas. Jurnal Administrasi Bisnis, Vol. 8, No. 2, pp: 1-10.

Riyanto, Bambang. 2011. Dasar-dasar Pembelanjaan Perusahaan. Edisi ke 4. Yogyakarta: Yayasan Penerbit Gajah Mada .

Ross, S., (1996). The Arbitrage Theory of Capital Asset Pricing. Journal of Economic Theory, 13, 341-60

Rudin M.*, Djayani Nurdin and Vita Yanti Fattah. 2016. The Effect Of Liquidity And Leverage On Profitability Of Property And Real Estate Company In Indonesian Stock Exchange. International. Journal of Social Sciencesand Management. Vol. 3, Issue-4: 300304.

Sartono, Agus. 2010. Manajemen Keuangan Teori dan Aplikasi. Yogyakarta: BPFE.

Sawir, Agnes. 2009. Analisis Kinerja Keuangan Teori dan Perencanaan Keuangan Perusahaan. Jakarta : PT.Gramedia Pustaka Umum.

Shyam-Sunder, L. \& Myers, C. (1999). Testing static tradeoff against pecking order models of capital structure. Journal of Financial Economics, 51, 219-244.

Silalahi, Ulber. 2012. Metode Penelitian Sosial. Bandung: PT Refika Aditama.

Sudana, I Made. 2011. Manajemen Keuangan Perusahaan Teori \& Praktek. Jakarta: Penerbit Erlangga.

Sugiyono, Arief. 2012, Metode Penelitian Kuantitatif Kualittif R\&B. Bandung. Alfabeta.

Sujarweni, V. Wiratna. 2014. Metode Penelitian: Lengkap, Praktis, dan Mudah Dipahami. Yogyakarta: Pustaka Baru Press.

Sunarto, dan Agus Prasetyo Budi, 2009. Jurnal. Pengaruh Leverage, Ukuran dan Pertumbuhan Perusahaan Terhadap
Profitabilitas. Universitas Stikubank : Semarang

Sunyoto, Danang. 2013. Analisis Laporan Keuangan untuk Bisnis ( Teori dan Kasus). Cetakan 1. Yogyakarta : Penerbit CAPS.

Suwito, Edy dan Herawaty. 2005. Analisis Pengaruh Karakteristik Perusahaan Terhadap Tindakan Perataan Laba Yang Dilakukan Oleh Perusahaan Yang Terdaftar Di BEJ. Simposium Nasional Akuntansi VIII Solo.

Syamsuddin, Lukman. 2013. Manajemen Keuangan Perusahaan : Konsep Aplikasi dalam Perencanaan, Pengawasan, dan Pengambilan Keputusan. Cetakan kedua belas. Jakarta : PT.Raja Grafindo Persada.

Van Horne, James C dan John M. Wachowicz, Jr. 2012. PrinsipPrinsip Manajemen Keuangan. Edisi 13. Buku 1. Jakarta : Salemba Empat.

Widarjono, Agus. 2013. Ekonometrika: Pengantar dan aplikasinya. Ekonosia, Jakarta.

Weston J. Fred dan Thomas E. Copeland. 1997. Manajemen Keuangan, Edisi Sembilan. Jakarta: Penerbit Bina Rupa Aksara.

Annual Report Perusahaan. www.idx.co.id, diakses 6 Oktober 2018.

Data mengenai daftar perusahaan. www.sahamok.com , http://idx.co.id/Portals/0/StaticData/Pu blication/FactBook/FileDownload/2018 0117_FB-2017.pdf , https://sahamprofit.co.id/properti-dankonstruksi-property-property/, diakses 3 Oktober 2018. www.napro.id/news/prediksiperkembangan-investasi-properti-di2018, diakses 20 Desember 2018. 